\title{
Penentuan Aktivitas Gabungan Ekstrak Etanol Pulosari (Alyxia reinwardtii) dan Secang (Sappan Lignum) Sebagai Inhibitor Tirosinase Yang Potensial Untuk Bahan Kosmetik Melalui Pendekatan In Silico dan In Vitro
}

Penulis

Afiliasi
Fadilah $^{1 *}$, Aryo Tedjo ${ }^{1}$, Rudi Heryanto ${ }^{2}$

${ }^{1}$ Departemen Kimia Kedokteran, Fakultas Kedokteran Universitas Indonesia, Indonesia

${ }^{2}$ Pusat Studi Biofarmaka, LPPM, Institut Pertanian Bogor, Indonesia

\section{Kata Kunci \\ $\rightarrow$ Tirosinase \\ $\rightarrow$ Pulosari (Alyxia reinwardtii) \\ - Secang (Sappan lignum) \\ - Polifenol \\ - Simulasi docking \\ ○ uji in vitro}

Diterima 20 Agustus 2015 Direvisi 8 Desember 2015 Disetujui 9 Februari 2016

*Penulis korespondensi Fadillah

Departemen Kimia

Fakultas Kedokteran Universitas Indonesia Jl. Salemba Raya No.06 Jakarta Pusat, Indonesia fadilah81@gmail.com

\begin{abstract}
Abstrak
Tirosinase atau fenol oksidase adalah enzim utama yang terlibat dalam biosintesis melanin. Untuk menghindari produksi melanin secara berlebihan pada lapisan epidermal, maka dicari senyawa yang mampu menghambat tirosinase sehingga dapat digunakan sebagai bahan pemutih kulit. Inhibitor enzim tirosinase dapat diperoleh dari senyawa bahan alam diantaranya, polifenol, kumarin, stilben sebagai pengganti senyawa sintetik. Tirosinase telah diketahui struktur molekular sehingga dapat diketahui mekanisme kerjanya melaui uji in-silico dan pembuktian secara in-vitro. Penelitian ini digunakan untuk mendeteksi keefektifan gabungan dari ekstrak etanol pulosari (Alyxia reinwardtii) dan secang (Sappan lignum) sebagai inhibitor tirosinase. Dari hasil in-silico pengujian aktivitas inhibisi tirosinase menggunakan software MOE 2008 menunjukkan bahwa dalam ekstrak etanol dari secang yaitu senyawa brazilin dan rhamnitin berturut-turut memiliki nilai $\Delta \mathrm{G}-15.6582 \mathrm{kkal} / \mathrm{mol},-13.3378 \mathrm{kkal} / \mathrm{mol}$ dengan inhibisi $10.021 \mu \mathrm{M}, 8.331 \mu \mathrm{M}$ dan Hdon-acc 6, 8. Sedangkan dalam ektrak etanol dari pulosari dengan senyawa scopoletin dan zhebeiresinol berturut-turut memiliki nilai $\Delta G-12.1661 \mathrm{kkal} / \mathrm{mol} ;-13.8982 \mathrm{kkal} / \mathrm{mol}$ dengan inhibisi $7.279 \mu \mathrm{M}$; 9.104 $\mu \mathrm{M}$ dan Hdon-acc 5 dan 6. Sedangkan senyawa parameter L-DOPA dan pembanding asam kojat berturut-turut memiliki nilai $\Delta G-9.8247 \mathrm{kkal} / \mathrm{mol} ;-8.8047$ $\mathrm{kkal} / \mathrm{mol}$ dengan inhibisi $5.592 \mu \mathrm{M} ; 4.976 \mu \mathrm{M}$ dan Hdon-acc 3; 3. Dari pembuktian secara in-vitro menunjukkan bahwa uji aktivitas inhibisi tirosinase berturut-turut dari secang (SI), pulosari (Ar), gabungan SI dan Ar dengan pembanding asam kojat memiliki nilai $I_{50}$ berturut-turut 797.090 ppm, 1962.934 ppm, 571.352 ppm dan $93.557 \mathrm{ppm}$. Sehingga dari hasil in-silico dan in-vitro disimpulkan bahwa penggabungan antara pulosari dan secang memiliki tingkat $\mathrm{IC}_{50}$ lebih baik dibandingkan pemberian masing-masing ekstrak.
\end{abstract}




\section{Pendahuluan}

Tirosinase (EC 1.14.18.1) adalah enzim multifungsi yang mengandung $\mathrm{Cu}$ yang secara luas terdistribusi di alam. Enzim ini terutama terlibat dalam dua langkah pertama dari biosintesis melanin, yang terdiri dari hidroksilasi L-tirosin (aktivitas monofenolase) dan oksidasi dari produk ini reaksi, Ldopa (aktivitas difenolase) (Kim et al. 2005). Enzim ini juga bertanggung jawab untuk pigmentasi kulit kelainan seperti bintik-bintik dan cacat (Seo et al. 2003). Tirosinase juga terkait dengan Parkinson dan lainnya penyakit neurodegenerative (Asanuma et al. 2003; Xu et al. 1998). Enzim tirosinase berperan dalam biosintesis melanin di dalam tubuh makhluk hidup. Melanin memiliki fungsi yang sangat penting yaitu untuk melindungi tubuh dari radiasi sinar ultraviolet dari matahari (Artes et al. 1998).

Di negara yang beriklim tropis, seperti Indonesia tentunya paparan sinar matahari tidak dapat dihindari, terlebih apabila seseorang diharuskan beraktivitas di luar ruangan dan kulitnya mengalami kontak langsung dengan sinar matahari. Namun, apabila pigmen melanin, diproduksi secara berlebih akan terjadi penumpukan melanin pada permukaan kulit (hiperpigmentasi). Untuk menghindari produksi melanin berlebih maka mekanisme tirosinase perlu dihambat, adanya inhibitor tirosinase ini, akan menghambat reaksi enzimatis dari tirosinase. Beberapa inhibitor tirosinase diantaranya arbutin, asam askorbat, asam kojat, merkuri dan hidrokuinon (Kim et al. 2005).

Beberapa Inhibitor tersebut diperoleh secara sintesis dan dari bahan alam. Senyawa alam diantaranya turunan polifenol yang berasal dari tumbuh-tumbuhan telah diselidiki sebagai inhibitor tirosinase untuk menghindari produksi melanin secara berlebihan pada lapisan epidermal, sehingga dapat digunakan sebagai bahan kosmetik (Zheng et al 2008). Senyawa alam diantaranya dalam tanaman Secang (Sappan lignum) dan Pulosari (Alyxia reinwardtii) memiliki kandungan kumarin, flavonoid, kalkon dan iridoit yang diprediksikan bisa menghambat aktivitas tirosinase (Kittagawa et al. 1988; Topcu et al. 1990; Lin et al. 1993; Steffan et al. 2005; Chen et al. 2008; Rattanappani et al. 2012).

Penggunaan senyawa alam terbukti lebih baik dan aman dibandingkan senyawa sintesis dalam menghambat metabolisme pigmentasi. Beberapa analog kumarin, esculetin, diisolasi dari biji Euphorbialathyris dan menunjukkan seperempat dari aktivitas antitirosinase asam kojat (Masamoto et al. 2003). Senyawa analog kumarin baru-baru ini terbukti merupakan substrat tirosinase dari jamur (Sollai et al. 2008). Analog kumarin yang lain yaitu 9hidroksi-4-metoksipsoralen yang diisolasi dari Angelica dahurica terbukti enam kali memiliki aktivitas inhibisi tirosinase dari pada asam kojat (Piao et al. 2004).

Baru-baru ini teknologi bioinformatik menemukan struktur tiga dimensi tirosinase, maka pembentukan kompleks protein-ligan sebagai inhibitor dapat diprediksi dengan simulasi komputasi, dimana prediksi ikatan dan perubahan konformasi kompleks dapat diketahui. Salah satu cara untuk mengetahui apakah terjadi interaksi ligan dengan protein adalah dengan simulasi docking. Simulasi docking adalah suatu simulasi perhitungan mekanika kuantum dan penghitungan energi bebas ikatan suatu senyawa (ligan) terhadap reseptor (dalam hal ini protein) untuk mengetahui apakah senyawa tersebut mampu berinteraksi dengan reseptor (Leach 2001; Luchintes 2004; Funkhouser 2007). Pertimbangan untuk melakukan penelitian ini melalui pendekatan molecular docking adalah cara ini akan membantu menseleksi komponen senyawa yang akan diuji secara in vitro sehingga membuat pekerjaan ekstraksi, isolasi, dan elusidasi senyawa aktif menjadi lebih efisien.

Mekanisme kerja enzim diduga akan menghasilkan senyawa yang lebih berdaya guna. Senyawa yang lebih menghambat kejadian dan proses yang spesifik dalam sistem pigmentasi. Diantara pilihan yang ada, penggunaan komponen bahan alam yang memiliki sifat memperbaiki dan kinerja lebih baik dari sintesis dapat dicoba pada enzim tirosinase. Oleh karena itu, Penelitian ini bertujuan untuk mengembangkan senyawa yang berasal dari tanaman asli Indonesia terpilih (pulosari dan secang) yang dapat berfungsi sebagai inhibitor tirosinase. Secara khusus penelitian ini bertujuan untuk memperoleh kandidat senyawa polifenol penghambat tirosinase dari pulosari dan secang yang berasal dari ekstrak etanolnya. Selain itu didapatkan pula bukti ilmiah penggunaan bahan alam gabungan 
dalam bentuk ekstrak kasar terkait keberadaan senyawa kandidat yang dapat menghambat. Hasil lain yang diharapkan dalam penelitian ini adalah didapatkan alur/model bagi penelitian bahan alam berdasarkan database yang ada sehingga dapat dihindari pengulangan penelitian yang telah dilakukan, sehingga akan mempercepat aplikasi penerapan bahan-bahan alam. Manfaat penelitian ini diharapkan dapat mendukung pengembangan produk pemutih kulit yang akan membantu masyarakat dunia untuk memperoleh senyawa-senyawa dalam ekstrak yang ampuh dan meningkatkan penggunaan bahan-bahan alam Indonesia serta mampu mengeksplorasi sumber alam kekayaan Indonesia ke kancah dunia. Riset ini juga diperlukan untuk mengembangkan produk-produk lebih jauh lagi sebagai bahan-bahan fitofarmaka modern yang nantinya dapat diakui di pasar dan diekspor ke negara lain.

\section{Metode Penelitian}

Penelitian ini dilakukan di Laboratorium Pusat Studi Biofarmaka LPPM Institut Pertanian Bogor dan Laboratorium Kimia Kedokteran Fakultas Kedokteran Universitas Indonesia. Bahan yang digunakan dalam penelitian ini adalah kulit batang tanaman pulosari dan secang dari daerah Bogor, etanol, bufer fosfat $\mathrm{pH}$ 6.5, $\mathrm{NH} 4 \mathrm{OH}$, alkohol, $\mathrm{HCl} 37 \%$, etanol 95\%, DMSO, LDOPA, L-tirosin, asam kojat, dan enzim tirosinase dari jamur (Sigma, 333 unit $/ \mathrm{mL}$ dalam bufer fosfat). Alat yang digunakan dalam penelitian ini adalah spektrofotometer UV-Vis (Shimadzu-UV 1700), multiplate reader, multi-well plate, penguap putar, dan alat-alat gelas.

\section{Uji in-vitro aktivitas inhibitor tirosinase}

Preparasi awal sampel dilakukan dengan memngambil sampel kulit batang dari secang dan pulosari. Sampel dikeringkan dan diserbukkan. Serbuk yang dihasilkan dimaserasi menggunakan etanol sebanyak 3 kali ulangan. Ekstrak yang diperoleh kemudian disaring dan filtratnya dipekatkan dengan menggunakan penguap putar pada suhu $30^{\circ} \mathrm{C}$.

Uji aktivitas inhibitor tirosinase (Batubara et al. 2010), ekstrak tanaman pulosari dilarutkan di dalam DMSO hingga konsentrasi $20 \mathrm{mg} / \mathrm{mL}$. Larutan stok disiapkan dengan cara melarutkan ekstrak pekat ke dalam bufer fosfat $50 \mathrm{mM}(\mathrm{pH}$ 6.5) hingga diperoleh konsentrasi $600 \mu \mathrm{g} / \mathrm{mL}$. Setelah itu, ekstrak diuji dengan konsentrasi 31-2000 $\mathrm{\mu g} / \mathrm{mL}$. Asam kojat sebagai kontrol positif juga diuji pada variasi konsentrasi yang sama dalam pelat tetes 96 sumur. Ekstrak sampel masing-masing ditambahkan sebanyak $70 \mu \mathrm{L}$ ke dalam pelat tetes 96 sumur. Kemudian ke dalam tiap sumur ditambahkan $30 \mu \mathrm{L}$ enzim tirosinase (Sigma, 333 unit/ml dalam bufer fosfat) dan campuran diinkubasi selama 5 menit. Setelah itu, sebanyak $110 \mu \mathrm{L}$ substrat (L-tirosin $2 \mathrm{mM}$ atau L-DOPA $12 \mathrm{mM}$ ) ditambahkan dan campurannya diinkubasi pada suhu $37^{\circ} \mathrm{C}$ selama 30 menit. Larutan pada masing-masing sumur diukur absorbansnya dengan menggunakan microplate reader pada panjang gelombang $492 \mathrm{~nm}$ untuk menentukan persen inhibisi dan nilai konsentrasi hambat $50 \%$ $\left(\mathrm{IC}_{50}\right)$. Persen inhibisi dihitung dengan cara membandingkan absorbans sampel tanpa penambahan ekstrak $(A)$ dan dengan penambahan ekstrak (B) pada panjang gelombang $492 \mathrm{~nm}$.

\section{Uji in-silico}

Preparasi tirosinase, sekuen tirosinase dapat di unduh dari database NCBI yang ada di National Center for Biotechnology Information melalui alamat situs http://www.ncbi.nlm.nih.gov/genomes/flu/ dengan menggunakan perangkat komputer yang terhubung dengan internet. Sekuen dari hasil searching dialignment menggunakan program Clustal W2. Program Clustal W2 disediakan secara online dengan mengakses www.ebi.ac.uk/Tools/clustalw2/index.html. Hasil alignment diinterpretasikan dengan score yang paling tinggi. Proses editing alignment digunakan software Bioedit. Pencarian struktur tiga dimensi tapak sekuen dilakukan dengan menggunakan Swiss model yang dapat diakses melalui http://swissmodel.expasy.org/SWISS-MODEL.html. yang dilakukan dengan menggunakan bantuan perangkat komputer yang terhubung dengan internet. Sistem operasi yang digunakan adalah Microsoft Windows XP dengan browser Mozilla Firefox 2.0. selanjutnya hasil struktur tiga dimensi dioptimasi geometri dan minimisasi energi struktur tiga dimensi tirosinase dilakukan menggunakan software MOE yang telah diunduh dengan format pdb. Kemudian dilakukan penambahan atom 
hidrogen dan dilakukan protonasi dengan program protonate 3D. Selanjutnya dilakukan pengaturan muatan partial dengan menggunakan partial charge dan optimasi dengan force field MMFF94x. Saat optimasi, solvasi enzim dalam bentuk gas phase dan dilakukan fix charge dengan RMS gradient 0.05 $\mathrm{kcal} / \mathrm{Amol}$, dan parameter yang lain menggunakan standar yang telah ada di software MOE.

Perancangan senyawa bioaktif, senyawa bioaktif dari pulosari dan secang dari studi jurnal dimodelkan ke dalam struktur tiga dimensi. Pemodelan ini dilakukan dengan menggunakan software ACD Labs. Bentuk tiga dimensi didapatkan dengan menyimpan dalam 3D viewer pada ACDLabs, dan struktur tiga dimensi disimpan dalam format MDL molfile. Selanjutnya format MDL Molfile diubah kedalam format MDL Mol menggunakan software Vegazz agar sesuai untuk proses docking. Selanjutnya kandidat ligan yang dirancang disimpan dalam format Mol dibuka dengan software MOE dalam bentuk database viewer. Selanjutnya ligan di wash dengan program compute, dilakukan penyesuaian muatan partial ligan dengan partial charge dan optimasi menggunakan forcefield MMFF94. Selanjutnya ligan diminimasi menggunakan energy minimize dengan RMS gradient $0.001 \mathrm{Kcal} / \mathrm{Amol}$. Parameter lainnya sesuai dengan default yang ada dalam software docking tirosinase terhadap ligan. Proses docking diawali dengan preparasi file docking yang dilakukan dengan menggunakan program docking yang terdapat dalam software MOE.

Simulasi docking dilakukan dengan program Compute-Simulation dock dengan operating system Microsoft Windows XP Professional. Metode penempatan menggunakan triangle mathcer dengan pengulangan pembacaan energi tiap posisi 2.000 .000 dan parameter yang lain sesuai yang ada dalam MOE. Selanjutnya scoring function menggunakan longdon dG, refinement forcefield dengan konfigurasi pengulangan populasi 1000 . Pengulangan yang pertama sebanyak seratus (100) kali dan pengaturan kedua hanya ditampilkan satu dari hasil yang terbaik dari 100 pengulangan.

Analisis docking, Hasil pembentukan kompleks docking enzim ligan ditampilkan dalam database viewer output pada halaman MOE. Parameter yang ditampilkan dan digunakan untuk analisis adalah energi bebas ikatan (Gbinding), Log $\mathrm{P}$, bobot molekul, konstanta inhibisi, ikatan hidrogen, konformasi inhibitor terhadap binding site enzim. Analisis dilakukan terhadap ligan kandidat dan sebagai parameter dilakukan analisis terhadap pembanding asam kojat dan L-dopa.

\section{Hasil dan Pembahasan}

Penapisan aktivitas ekstrak kasar etanol sampel pulosari dilakukan untuk mengetahui ekstrak yang berfungsi sebagai inhibitor enzim tirosinase. Aktivitas inhibitor enzim tirosinase ditunjukan dari daya inhibisi yang tertera pada Tabel 1 . Ekstrak etanol yang digunakan adalah kulit batang pulosari dan secang, dengan pembanding asam kojat dan parameter L-DOPA. Tabel 1 menunjukan bahwa sampel yang memiliki aktivitas sebagai inhibitor enzim tirosinase yang baik adalah campuran antara pulosari dan secang dengan komposisi 1:1. Beberapa senyawa flavonoid yang diketahui memiliki aktivitas sebagai inhibitor enzim tirosinase diantaranya golongan senyawa flavonol (kuersetin), flavon (noratokarpetin), flavanon (stepogenin), flavanol (dihidromorin dan taksifolin), isoflavan (gliasperin C, glabridin), kalkon, dan isoflavon (Kalikosin) (Chang et al. 2009).

Hasil yang diperoleh mendukung pendugaan senyawa aktif gabungan dari keduanya banyak mengandung senyawa flavonoid dan kumarin. Dimana senyawa golongan flavonol telah diketahui mempunyai potensi sebagai inhibitor tirosinase. Senyawa flavonol yang aktif sebagai inhibitor tirosinase diantaranya adalah kaempferol, misertin, dan kuersetin (Chang et al. 2009). Perbedaan senyawa flavonol dengan senyawa flavonoid lainnya dapat dilihat dari strukturnya. Senyawa flavonol memiliki gugus 3-hidroksi. Hal ini juga yang dapat menyebabkan flavonol lebih aktif sebagai inhibitor tirosinase. Sisi tempat gugus hidroksi menempel pada struktur benzena dan juga jumlah gugus hidroksil pada suatu flavonoid berperan penting dalam proses penginhibisian aktivitas enzim tirosinase (Donghyun et al. 2006). Hal ini ditunjang oleh data dari hasil uji in-silico pada Tabel 2. Dari hasil uji in-silico pendekatan docking interaksi antara enzim tirosinase dengan ligan dari senyawa bioaktif pulosari dan secang SI sebagaimana Tabel 2. Hasil docking menunjukkan bahwa dari 8 senyawa bioaktif dari pulosari (Rattanappani et al. 2012) dan 13 senyawa 
bioaktif dari secang (Chen et al. 2008) dengan enzim tirosinase, ada 4 senyawa aktif yang mampu menginhibisi tirosinase lebih baik dan memiliki energi Gibbs rendah dibandingkan dengan senyawa pembanding asam kojat. Energi Gibbs ikatan merupakan energi ikatan antara enzim dengan inhibitor pada kondisi kesetimbangan, maka dengan terhitungnya energi gibbs kekuatan dan kestabilan interaksi antara kompleks enzim dan ligan dapat diketahui. Dalam software MOE energi Gibbs dilambangkan dengan $\mathrm{S}$ yang menunjukkan jumlah total dari tahapan akhir docking. Nilai $S$ memiliki score yang sama dengan $E_{-}$refine, dimana $E_{-}$refine merupakan energi total dari ikatan kompleks docking. Dari tabel 2 menunjukkan bahwa tingkat nilai S yang paling rendah adalah senyawa SI1 dari secang dan Ar5 dari pulosari berturut-turut dengan nilai $\mathrm{S}$ -
$15.1582 \mathrm{kkal} / \mathrm{mol} ; 13.8982 \mathrm{kkal} / \mathrm{moldan} \quad \mathrm{pKi}$ $10.021 \mu \mathrm{M}, ; 9.104 \mu \mathrm{M}$ dan lebih rendah dibandingkan dengan senyawa pembanding asam kojat dengan $\mathrm{S}$ $8.8047 \mathrm{kkal} / \mathrm{mol}$. Dimana $\Delta \mathrm{G}$ adalah energi bebas gibbs, $\mathrm{R}$ adalah tetapan gas konstan $(\mathrm{J} / \mathrm{mol} \mathrm{K}), \mathrm{T}$ adalah temperatur absolut (K) dan KA adalah konstanta aktifitas enzim, $\mathrm{Ki}$ adalah konstanta inhibitor (Kitchen et al. 2004) Dari persamaan diatas, maka semakin kecil nilai Ki kesetimbangan reaksi dan afinitas ikatan cenderung stabil dalam pembentukan kompleks. Data docking dari software MOE menunjukkan nilai konstanta inhibisi dalam pKi. Artinya semakin besar nilai pKi, maka ligan memiliki Ki yang kecil. Maka nilai pKi ini dapat digunakan untuk mengetahui tingkat keefektifan dalam pembentukan kompleks enzim dengan ligan.

Tabel 1. Hasil uji penghambatan ekstrak etanol terhadap tirosinase

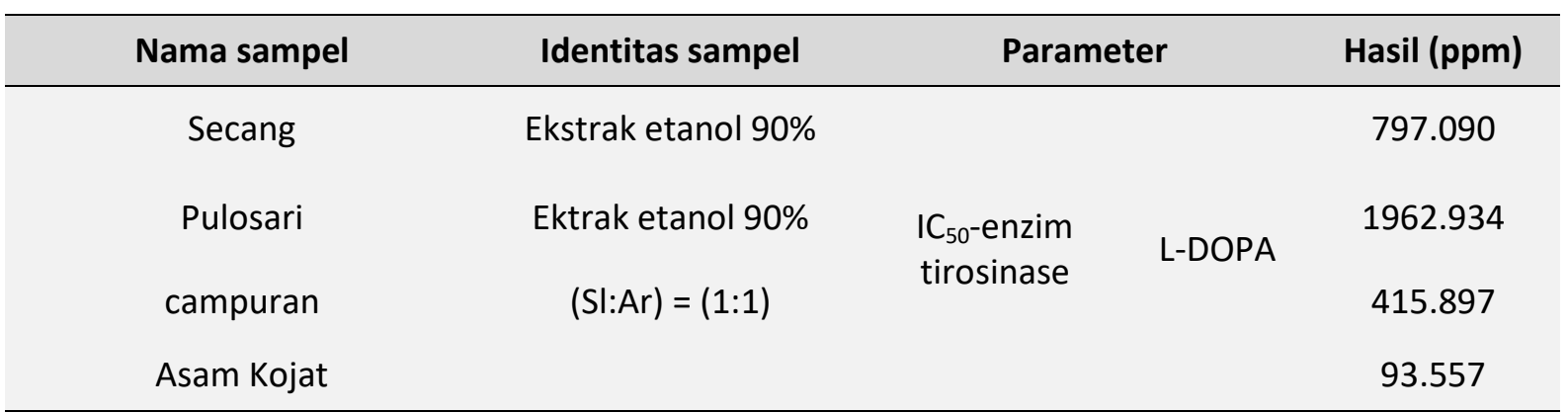

Tabel 2. Hasil docking dan minimasi energi antara ligan dengan tirosinase

\begin{tabular}{lcccccc}
\hline \multicolumn{1}{c}{ Ligan } & Ar1 & Ar5 & Sl1 & Sl8 & L-dopa & AK \\
\hline Energi & -12.1661 & -14.8982 & -15.1582 & -13.3378 & -9.8247 & -8.9047 \\
pKi & 7.979 & 9.104 & 10.021 & 8.331 & 5.592 & 4.976 \\
H Don & 5 & 6 & 6 & 8 & 3 & 5 \\
Hacc & & & & & & \\
\hline
\end{tabular}

Ket : Ar1: Scopoletin, Ar5: Zheberesinol, SI1: Brazilin, Sl8: Rhamnitin, AK: Asam kojat 
Dari hasil docking nilai pKi dari ligan SI1 dan Ar5 yaitu $10.021 \mu \mathrm{M} ; 10.021 \mu \mathrm{M}$, nilai ini menunjukkan bahwa ligan SI1 dan Ar8 memiliki afinitas dan berinteraksi lebih kuat dalam membentuk kompleks dengan tirosinase dibandingkan dengan senyawa pembanding dengan pKi $4.976 \mu \mathrm{M}$. Analisis ikatan hidrogen dan interaksi merupakan gaya antramolekul yang terjadi pada atom yang memiliki keelektronegatifan tinggi dengan hidrogen yang terikat secara kovalen pada atom elektronegatif. Ikatan hidrogen dari kompleks tirosinase dengan ligan hasil docking diidentifikasi dengan software MOE program LigX interactions. Hasil identifikasi ikatan hidrogen antara residu asam amino tirosinase dengan ligan SI1 dan Ar8 dan ligan pembanding seperti dalam Tabel 2.

Dari Tabel 2 menunjukkan bahwa ligan SI1 dan Ar5 dan ligan standar asam kojat membentuk ikatan hidrogen secara berturut-turut 6,6 dan 3 ikatan. Ikatan hidrogen berperan terhadap afinitas ligan dalam membentuk kompleks dengan enzim tirosinase hal ini disebabkan adanya interaksi elektrostatik antara atom oksigen atau hidrogen ligan dengan atom hidrogen asam amino ataupun sebaliknya. Kontak residu merupakan interaksi residu enzim tirosinase dengan ligan (inhibitor). Interaksi yang terjadi antar kompleks enzim ligan adalah interaksi

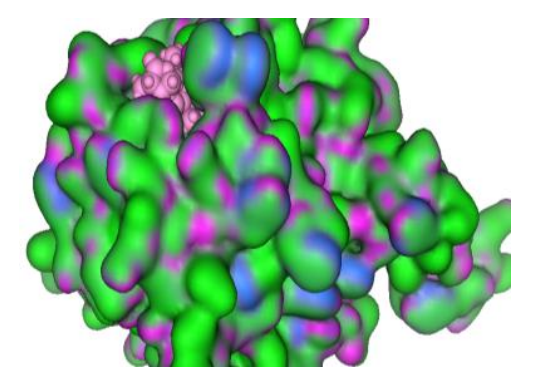

Gambar 1. Kompleks Ar1-tirosinase

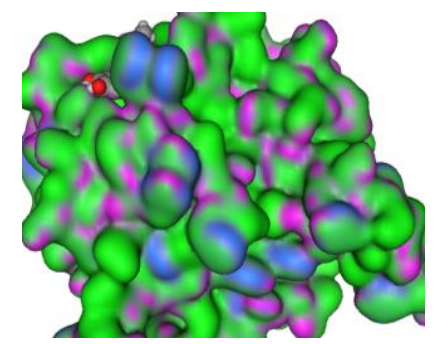

Gambar 3. Komplek SI1-tirosinase hidrogen, selain itu juga terjadi interaksi non kovalen yang sangat mempengaruhi stabilitas enzim. Interaksi hidrofob yang menyebabkan protein dapat mempertahankan integrasinya karena folding, serta interaksi aromatik yang mempengaruhi stabilitas struktur tersier. Kontak residu antara ligan dengan enzim tirosinase hasil docking dapat diketahui dengan software MOE program LigX interaction. Berdasarkan hasil yang diperoleh menunjukkan bahwa kontak residu antara semua ligan dengan tirosinase menunjukkan mekanisme penghambatan kompetitif dengan substrat yaitu L-DOPA memiliki konformasi penempatan penghambatan sama dengan ligan-ligan lainnya.

Gambar 1-6 menunjukkan bahwa interaksi ligan dengan sisi katalitik tirosinase terlihat bahwa senyawa SI1 dan Ar5 memiliki interaksi lebih baik dibandingkan dengan senyawa asam kojat. Menurut hasil ini melalui pendekatan docking bahwa senyawa diatas dapat digunakan sebagai senyawa inhibitor tirosinase. Pemberian ekstrak yang bersamaan dalam in-vitro membuktikan bahwa kedua tanaman ini mengandung senyawa golongan flavonoid dan kumarin yang telah diketahui mempunyai potensi sebagai inhibitor tirosinase. Senyawa flavonol yang aktif sebagai inhibitor tirosinase diantaranya adalah kaempferol, misertin, dan kuersetin (Chang 2009).

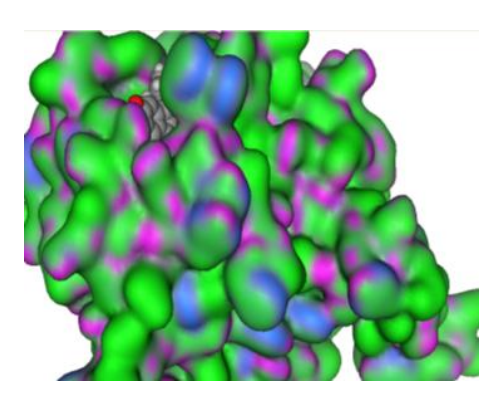

Gambar 2. Kompleks Ar5-tirosinase

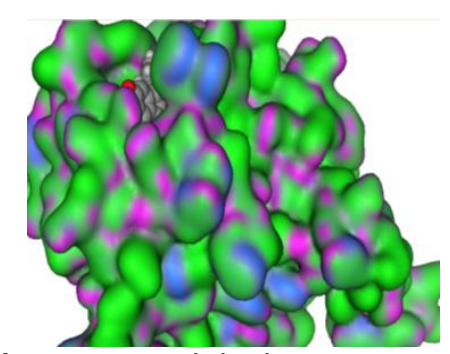

Gambar 4. Komplek Sl8-tirosinase

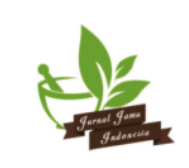




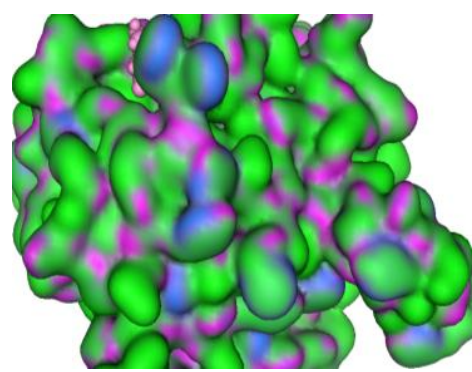

Gambar 5. Komplek asam kojat-tirosinase

\section{Kesimpulan}

Hasil penelitian ini menunjukkan bahwa gabungan ekstrak etanol kulit batang pulosari dan secang dapat digunakan sebagai inhibitor tirosinase, melalui pendekatan in silico senyawa dalam Ar dan SI memiliki nilai inhibisi yang lebih baik dibandingkan senyawa pembanding asam kojat dan sebagai ligan kompetitif yang mengisi katalitik site sesuai dengan konformasi L-DOPA. Pembuktian secara in vitro menunjukkan bahwa pemberian ekstrak yang bersamaan memiliki nilai inhibisi yang lebih tinggi dibandingkan dengan pemberian masing-masing ekstrak.

\section{Daftar Pustaka}

Artés F, Castañer M, Gil MI. 1998. Review: enzymatic browning in minimally processed fruit and vegetables. Journal of Agricultural and Food Chemistry. 4:377-389.

Asanuma M, Miyazaki I, Ogawa N. 2003. Dopamineor L-DOPA induced neurotoxicity: the role of dopamine quinone formation and tyrosinase in a model of Parkinson's disease. Neurotoxicity Research. 5:165-176.

Steffan B, Wätjen W, Michels G, Niering P, Wray V, Ebel R, Edrada R, Kahl R, Proksch P. 2005. Polyphenols from plants used in traditional Indonesian medicine (Jamu): uptake and antioxidative effects in rat H4IIE hepatoma cells. Journal of Pharmacy and Pharmacology. 57:233-240.

Batubara I, Darusman LK, Mitsunaga T, Rahminiwati M, Djauhari E. 2010. Potency of Indonesia medicinal plants as tyrosinase inhibitor and antioxidant agent. Journal of Biological Sciences. 10:138-144.

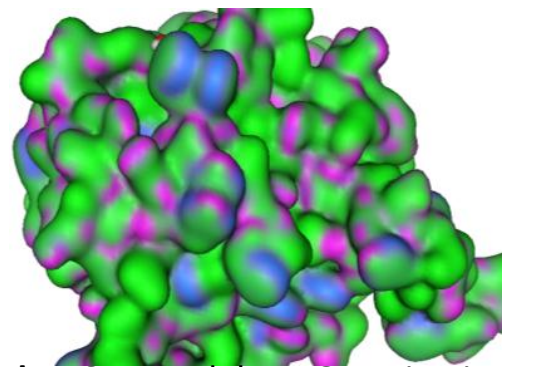

Gambar 6. Komplek L-DOPA-tirosinase

Chang TS. 2009. An update review of tyrosinase inhibitors. J Mol Sci 10:2440-2473.

Donghyun $K$, Jiyeoun $P$, Jinhee $K$, Cheolkyu $H$, Jeonghyeok $\mathrm{Y}$, Namdoo $\mathrm{K}$, Jinho $\mathrm{S}$, Choonghwan L. 2006. Flavonoids as mushroom tyrosinase inhibitors: a fluorescence quenching study. Journal of Agricultural and Food Chemistry. 54:935-941.

Funkhouser, Thomas. 2007. Lecture : Protein-Ligand Docking Methods. Princeton University.

Topcu G, Che CT, Cordell GA, Ruangrungsi N. 1990. Iridolactones from Alyxia reinwardti. Phytochemistry. 29(10), 3197-3199.

Kitagawa I, Shibuya H, Baek NI, Yokokawa Y, Nitta A, Wiriadinata H, Yoshikawa M. 1988. Pulosarioside, a new bitter trimericiridoiddiglucoside from an Indonesian Jamu, the bark of Alyxia reinwardtii BL. (Apocynaceae). Chemical and Pharmaceutical Bulletin. 36:4232-4235

Lin L, Lin LZ, Ruangrungsi N, Cordell GA. 1993. 3Hydroxycoumarin glycosides from Alyxia reinwardtii var. Lucida. Phytochemistry. 34:825-830.

Leach RA. 2001. Molecular Modelling Principle and Application. Ed ke-2. Chichester (UK) : Pearson Education Limited.

Lucientes, Gil MT. 2004. Protein Docking and Interactions Modeling

Masamoto $\mathrm{Y}$, Ando H, Murata $\mathrm{Y}$, Shimoishi $\mathrm{Y}$, Tada M, Takahata K. 2003. Mushroom tyrosinase inhibitory activity of esculetin isolated from seeds of Euphorbia lathyris L. Bioscience, Biotechnology, and Biochemistry. 67:631-634.

Piao XL, Baek SH, Park MK, Park JH. 2004. Tyrosinaseinhibitory furanocoumarin from Angelica 
dahurica. Biological and Pharmaceutical Xu Y, Stokes AH, Roskoski RJr. Vrana KE. 1998. Bulletin. 27:1144-1146.

Rattanapani J, Sichaem J, Tip-pyang S. 2012. Chemical Constituents and Antioxidant Activity from the Stems of Alyxia reinwardtii. Records of Natural Products. 6:3. 288-291

Seo SY, Sharma VK, Sharma N. 2003. Mushroom tyrosinase: recent prospects. Journal of Agricultural and Food Chemistry. 51:28372853.

Sollai F, Zucca P, Sanjust E, Steri D, Resciqno A. 2008. Umbelliferone and esculetin: inhibitors or substrates for polyphenol oxidases. Biological and Pharmaceutical Bulletin. 31:2187-2193. Dopamine, in the presence of tyrosinase, covalently modifies and inactivates tyrosine hydroxylase. Journal of Neuroscience Research. 54:691-697.

Chen YP, Liu L, Zhou YH, Wen J, Jiang Y, Tu PF. 2008. Chemical constituents from Sappan lignum. Journal of Chinese Pharmaceutical Sciences. 17:82-86.

Zheng ZP, Cheng KW, Chao J, Wu J, Wang M. 2007. Tyrosinase inhibitors from paper mulberry (Broussonetia papyrifera). Journal Food Chemistry. 106:529-535. 